\title{
K otázce etnické identity Rusínů v České republice
}

\author{
Andrej Sulitka
}

DOI: 10.21104/CL.2016.3.07

To the problem of ethnic identity of the Ruthenes in the Czech Republic

Abstract The text presents the problem of the situation of the Ruthenian national minority within the frame of the presentday ethnic structure of Czech Republic. It focuses on the selected activities that at present influence the processes of construction of identity of national minorities. It explains these problems on the example of the revival of communal life of Ruthenians in Prague. Besides the older basis, constituted by the Society of Friends of Subcarpathian Ruthenia or other associations was in the year 2011 established a new organization, Ruthenians.cz - Ruthenian Initiative in the Czech Republic. Its membership consists of members of younger generation of Ruthenians, immigrants from eastern Slovakia. This organization established as its goal to influence actively the developments in the communal life of Ruthenians in Prague, preserve and propagate Ruthenian cultural traditions and inform the Czech public on Ruthenians. The activities consist in cultural and communal events, public lectures, discussions, film projections etc. This initiative also helped to instigate communication among Ruthenians on social networks. The process of construction of identity of national minority is in the case of the Ruthenians based primarily on the delimitation against Ukrainians, accentuation of Ruthenian traditions and the their peculiarity.
Keywords Ruthenian national minority in the Czech Republic, minoritarian associations in Prague, Ruthenian associations, minoritarian activities of the Ruthenians, self-identification of Ruthenians against Ukrainians, sources of Ruthenian identity.

Příspěvek byl zpracován s institucionální podporou Etnologického ústav AV ČR, v. v. i., RVO:68378076.

Contact PhDr. Andrej Sulitka, CSc., Etnologický ústav AV ČR, v. v. i., Na Florenci 3, 11000 Praha 1, Czech Republic; e-mail: sulitka.andrej@seznam.cz.

Jak citovat / How to cite Sulitka, Andrej. (2016). K otázce etnické identity Rusínů v České republice. Český lid 103, 451-472. doi:http://dx.doi.org/10.21104/CL.2016.3.07 


\section{Úvodem}

Národnostně menšinový ruch Rusínů v českých zemích provází v současnosti aktivity, které směřují k oživení jejich menšinového života. Jedním z impulzů bylo založení nové organizace Rusíni.cz - Rusínská iniciativa $v$ ČR (dále jen Rusíni.cz) koncem roku 2011. ${ }^{1}$ Tato organizace sdružuje především příslušníky mladé generace Rusínů, zejména migranty z východního Slovenska. Vedle generačně starší členské základny Společnosti přátel Podkarpatské Rusi (dále jen SPPR), brněnské organizace Přátelé Podkarpatské Rusi, chomutovského folklorního sdružení Skejušan, ale i dalších málo aktivních sdružení (např. Rusíni a prátelé Podkarpatské Rusi či Sotružestvo Rusiniv) si nová organizace Rusíni.cz stanovila za cíl rozvíjet činnost v oblasti komunitního života Rusínů v ČR, uchovávat a propagovat kulturní hodnoty a tradice Rusínů, informovat českou veřejnost o Rusínech a jejich historii. ${ }^{2}$ Do spolkového života tradiční rusínské menšiny tak vstoupila spontánní iniciativa, která vyplynula z neformálních uskupení Rusínů v Praze, jejichž příslušníci komunikují často na sociálních sítích. Rusíni.cz jako menšinová organizace má záměr sdružovat mladou a střední generaci Rusínů žijících v českých zemích, a to bez ohledu na oblasti, z nichž migrovali, tj. různých východoslovenských regionů. ${ }^{3}$

Postavení spolku Rusíni.cz se vyznačuje tím, že se setkává s podporou statutárních zástupců SPPR a rovněž v prostředí její členské základny jsou aktivity nové organizace vnímány kladně. Rozšíření oficiální spolkové organizační struktury s právní subjektivitou znamená v tomto případě novou platformu pro rozvíjení aktivit rusínské menšiny. Jedním z konkrétních počinů spolku Rusíni.cz je realizace projektů „Rusíni v ČR - mlčící menši-

1 http://ekolist.cz/cz/zpravodajstvi/zpravy/nove-vytvorene-obcanske-sdruzeni-rusini-czrusinska-iniciativa-v-cr-se-usiluje-sdruzit-rusini-zijici-v-cr?add_disc=1 [2015-05-19]. V současnosti má organizace Rusíni.cz - Rusínská iniciativa v ČR právní subjektivitu a jako spolek sídlí v Domě národnostních menšin v Praze - viz http://rejstrik-firem. kurzy.cz/22769251/rusinicz-rusinska-iniciativa-v-cr/statisticky-urad/ [2015-06-11].

2 O rozvoj aktivit rusínské menšiny po roce 1990 se zasloužili zvláště Jaromír Hořec a Agáta Pilátová, kteří v rámci edice Podkarpatská Rus Společnosti přátel Podkarpatské Rusi a její rusínské sekce věnovali pozornost vydávání publikací o Podkarpatské Rusi a Rusínech v českých zemích (viz Hořec 1998). Vedle toho samostatně usiloval o prezentaci Rusínů v Praze Rudolf Matola, který jako solitér (bez spolupráce s příslušníky rusínské národnosti) vydal brožuru Historie Rusínů v Praze. Tiskovinu vydalo Obščestvo Rusínů v ČR, jehož byl předsedou (Matola 2001). Z důvodů subjektivistických interpretací autora jeho práce nenašla v pražském prostředí Rusínů kladnou odezvu.

3 Otevřenou otázkou je vztah k rusínským imigrantům ze Zakarpatské Ukrajiny (v českém kontextu Podkarpatské Rusi), konkrétně sdružení Sotružestvo Rusiniv, ke kterému se hlásí část ukrajinských migrantů za prací v Česku. Jde o skupinu Rusínů, kteří ovšem neprojevují zájem o trvalé usídlení v ČR. Jejich prioritou je udržet si místo na pracovním trhu a finančně podporovat své rodiny žijící na Zakarpatské Ukrajině. 
na“, „Cestou rusínské tradice“, „Rusíni o nás s vámi“ apod. ${ }^{4}$ Těmito projekty se snaží oslovit rusínské společenství v ČR, aby se jeho př́íslušníci hlásili k odkazu kulturních tradic Rusínů. Vlastní činnost směřuje k rozšíření programů kulturních a společenských akcí, přednášek, besed a filmových projekcí jakož i mediální prezentace rusínských aktivit, zvláště osobností s rusínskými kořeny, které jsou etablovány v prostředí české většinové společnosti. Pokud jde o vztah k Ukrajincům, respektive ukrajinské menšině v ČR, zástupci organizace Rusíni.cz - a podobně i SPPR - ho ve svých postojích charakterizují jako indiferentní: spolupracují sice se zástupci ukrajinských organizací, nicméně zaujímají zdrženlivý odstup od ukrajinských imigrantů v ČR.

Úvodem je třeba připomenout, že Rusíni v českých zemích prošli/procházejí složitým vývojem národního hnutí, v němž se odrážejí historické peripetie vývoje Podkarpatské Rusi (Bama 1994; Hubený 2012; Magocsi 2014; Pop 2011). Rusíni z Podkarpatské Rusi migrovali do českých zemí spolu s ukrajinskou a ruskou emigrací zejména po vzniku samostatného Československa 1918. Období meziválečného Československa je také považováno za klíčovou etapu ve vývoji rusínského národního hnutí a formování kolektivní identity Rusínů (Ševčenko 2006). Přítomnost Rusínů v ČR je tedy obecně spojována s oblastí Zakarpatské Ukrajiny, ${ }^{5}$ územím bývalé Podkarpatské Rusi, která byla součástí první Československé republiky a po druhé světové válce byla připojena k Ukrajině v rámci Sovětského svazu (srov. Magocsi 2014; Novotná 2005).

\section{Dotazníkové šetření mezi příslušníky rusínské menšiny, jeho cíle a metoda}

Cílem příspěvku je osvětlit vybrané aktivity v životě Rusínů v Česku, které mají v současnosti vliv na vytváření konstrukce národnostně menšinové identity. Při jejím studiu vycházíme z poznatků z výzkumu vzorku zástupců rusínské národnosti v roce 2015. Výzkum se uskutečnil v Praze a zahrnoval členy rusínských spolků, respektive jejich sympatizantů nejen z Prahy, ale i jiných měst, pokud se účastní akcí Rusínů v Praze. Výzkum byl koncipován

4 Viz http://www.dnm-praha.eu/BLOG/Rusinska-nm; podrobněji http://www.rusini.cz [2015-0609] a hlavně aktuální bilance rusínských aktivit ve Zprávě o situaci národnostních menšin za rok 2014, kterou zpracovala Dagmar Březinová, členka Rady vlády pro národnostní menšiny za rusínskou národnostní menšinu. Viz http://www.vlada.cz/cz/ppov/rnm/aktuality/zpravao-situaci-narodnostnich-mensin-v-ceske-republice-za-rok-2014-131806/ [2015-06-18].

5 V Česku přitom současní rusínští migranti ze severovýchodního Slovenska nehovoří o vazbě k území, které dostalo po druhé světové válce oficiální název Oblast Zakarpatská Ukrajina; v komunikaci uvádějí jak zástupci spolku Rusíni.cz, tak SPPR důsledně název Podkarpatská Rus, proto ho používáme i v dalším textu. 
jako anonymní dotazníkové šetření. ${ }^{6} \mathrm{Na}$ základě kontaktů se zástupci rusínských spolků byl dotazník respondentům rozeslán k vyplnění prostřednictvím organizace Rusíni.cz i zástupců SPPR elektronickou poštou (část dotazníků byla členům spolku rozdána také osobně) v celkovém počtu necelých 30 ks. Vzhledem k tomu, že většina respondentů vyplnila dotazníky jen částečně, uskutečnily se následně řízené rozhovory podle schématu otázek v dotazníku. Ty byly prováděny při setkáních menší skupiny členů spolků (8-10 osob), ale též individuálně. Průběh rozhovorů byl zaznamenáván diktafonem. ${ }^{7}$

Záměrem šetření bylo shromáždit poznatky o komponentech národnostně menšinové identity Rusínů. Dotazník byl koncipován jako podklad pro výzkumné šetření a oslovoval Rusíny - občany ČR i SR, kteří se účastní ve větší či menší míře spolkového života. Otázky v první části dotazníku se týkaly původu respondenta, jeho vzdělání, místa bydliště (v Praze MČ) a zaměstnání. Druhá část otázek směřovala k mapování představ o domově respondenta a jeho hodnocení podmínek usídlení v ČR. Těžiště třetí části představoval zájem o uchovávání zvyků a kulturních tradic původního domova v českém prostředí, dotazy ve čtvrté části se zaměřily na užívání rusínštiny jako menšinového jazyka v rodinném i veřejném životě, vědomí národnostně menšinové osobitosti, angažovanost ve spolkovém životě, náboženské vyznání, vztah k příslušníkům jiných menšin a představu o perspektivě rozvoje menšinového života Rusínů v Česku.

Skladbu respondentů, na které v příspěvku odkazujeme, tvořila skupina osob spojená s členskou základnou SPPR a hlavně s organizací Rusíni.cz; $z$ celkového počtu 28 osob bylo 12 žen ve věku 25 až 80 let a 16 mužů ve věku 26 až 44 let.

Ženy:

- občanství ČR - 6 osob, věková skupina od 50 let výše převážně se středoškolským vzděláním (pouze 1 respondentka uvedla vysokoškolské vzdělání),

- občanství SR - 6 osob (výjimkou je respondentka s dvojím občanstvím - SR a ČR), věková skupina 25 až 58 let převážně s vysokoškolským vzděláním (pouze 1 respondentka uvedla středoškolské vzdělání).

Obě skupiny respondentek vykazují tedy výrazně odlišnou věkovou i vzdělanostní charakteristiku. Nejedná se o cílený výběr. Složení je výsledkem

Chtěl bych poděkovat všem respondentům a respondentkám za spolupráci při uskutečnění výzkumu. V zájmu zachování anonymity respondentů jsou shromážděné dotazníky, na které v dalším textu odkazujeme, označeny v závorce arabskou číslicí, za pomlčkou je uveden údaj o občanství (ČR nebo SR) respondenta a dále jeho pohlaví a věk. Při transkripci vyjádření respondentů nebyla jazyková podoba jejich projevů upravována. Citaci vyjádření proto uvádíme ve slovenštině nebo v češtině, resp. v rusínském dialektu. Přísluší na tomto místě uvést, že dotazník byl zpracován v češtině, ale otázky při řízeném rozhovoru byly pokládány slovensky. To způsobilo, že odpověd' respondentů variovala mezi češtinou, pokud se přidržovali sledu otázek v dotazníku, a slovenštinou, dokonce u týchž informátorů či informátorek. 
spontánního zájmu členské základny spolků spolupracovat při realizaci výzkumu a uplatnění metody tzv. sněhové koule. Přísluší také uvést, že skupinu s českým občanstvím tvoří až na jednu výjimku členky spolku SPPR, se slovenským občanstvím spolku Rusíni.cz.

Muži:

- občanství ČR - 4 osoby ve věku 26 až 41 let, vysokoškolské vzdělání, náleží k členské základně SPPR,

- občanství SR - 12 osob ve věku 25 až 39 let, z toho 6 s vysokoškolským vzděláním a 4 se středoškolským, všichni z členské základny Rusíni.cz.

Kromě uvedeného úhrnu respondentů, kteří reagovali na vyplnění dotazníků a účastnili se následných řízených rozhovorů při společných setkáních, šlo o individuální rozhovory se zástupci spolku Rusíni.cz a rovněž SPPR. Citace výpovědí respondentů, které uvádíme v textu, jsou ponechány v podobě, jak byly zaznamenány v dotazníku, nebo podle jazykové stylizace respondenta při rozhovoru. Pokud jde o rozhovory s respondenty z členské základny SPPR, komunikace probíhala v českém jazyce, ale zástupci spolku Rusíni.cz reagovali na dotazník v českém jazyce většinou slovensky, přičemž navzájem mezi sebou komunikovali v dialektech rusínštiny.

Z metodologického hlediska se zpracování příspěvku opírá o poznatky z poměrně malého výzkumného vzorku respondentů dvou rusínských spolků, jejichž členská základna aktivních zástupců - podobně jako v př́ípadě jiných organizací národnostních menšin - čítá jen desítky osob. Vybranou skupinu zástupců rusínské menšiny tak lze považovat za reprezentativní vzorek v rámci organizačních uskupení Rusínů v ČR. Materiálovou databázi tvoří vedle dotazníkového šetření výsledky kvalitativního výzkumu. Ze zaměření výzkumu vyplývá, že nereflektujeme chápání Rusínů jako součásti ukrajinské národnosti, což doposud na Slovensku stále rezonuje v rusínských i ukrajinských menšinových organizacích, ale i v odborných kruzích. ${ }^{8}$ Jelikož v procesu transformace společnosti po listopadu 1989 zástupci Rusínů v českých zemích jasně deklarovali přání, aby byli považováni za samostatnou národnostní menšinu, akceptujeme tento postoj. Z tohoto důvodu v textu nepoužíváme pojmy „rusínská-ukrajinská“, „rusínská/ukrajinská“, resp. „rusínská (ukrajinská)“ či varianty formulované obráceně, jako „ukrajinská (rusínská)“ apod. národnostní menšina. ${ }^{9}$

8 Doposud v historické i etnologické ukrajinistické literatuře na Slovensku je odmítáno vymezování Rusínů a Ukrajinců jako dvou samostatných národnostních skupin (srov. např. nejnověji Sopoliga 1997; Sopoliga 2002 a další). Oproti tomu o autonomnosti rusínského fenoménu na Slovensku hovoří jasně v poslední době realizované výzkumy, mj. rozsáhlejší etnosociologický výzkum „Sebareflexia postavenia a vývoja Rusínov na Slovensku“ z roku 2002 (koordinátor projektu Ján Lipinský, odborná spolupráce Stanislav Konečný, František Baumgartner, Miroslav Frankovský, Marián Gajdoš). Výsledky výzkumu jsou prezentovány v elektronické publikaci. Vydal Róbert Vico-vydavatel'stvo v roce 2002. Dostupné z: lemko.org/rusyn/sebareflexia.pdf [2016-06-17].

9 Pojem „ukrajinská (rusínská)“ národnost uvádí i dnes již zrušený ústavní zákon č. 144/1968 Sb., o postavení národností v Československé socialistické republice (derogován byl přijetím ústavního zákona č. 23/1991 Sb., kterým se uvozuje Listina základních práv a svobod jako ústavní zákon FS ČSFR). 


\section{Rusíni jako národnostní menšina v ČR}

Rusínská národnostní menšina zaujímá ve skladbě národnostních menšin České republiky specifické místo. O Rusínech v českých zemích totiž nevypovídají oficiální statistické ukazatele ze sčítání lidu v letech 1921 až $1980 .{ }^{10}$ Po druhé světové válce v období komunistického režimu bránila též řada politických důvodů uvádět samostatně rusínskou národnost. ${ }^{11}$ Rusíni si však vybojovali své vlastní národnostně menšinové postavení až po listopadu 1989. Na Slovensku se jasně vymezili vůči ukrajinské menšině, vytvořili samostatné rusínské menšinové organizační struktury a rozvinuli nejen vlastní spolkovou činnost, ale především v rámci slovenské menšinové politiky položili institucionální základy celého spektra rusínské menšinové kultury (Gajdoš a kol. 2001; Plišková 2008), rusínského jazyka a školství (Plišková 2008) a rovněž náboženského života v souvislosti s rehabilitací řeckokatolické církve (Timkovič 2006). Reflexe tohoto vývoje se v menšinovém životě Rusínů v českých zemích projevila jen v omezené míře. Jejich menšinové zájmy po listopadu 1989 zprvu hájila pouze SPPR.

Rusíni teprve od roku 1991 využívají při sčítání lidu možnost svobodné volby deklarování národnostní příslušnosti. ${ }^{12}$ Následující sčítání lidu v letech 2001 a 2011 ukázala, že počet přihlášení se k rusínské národnosti má výrazně klesající tendenci. Proto zástupci tradičně usídlené rusínské menšiny uvítali vznik nového spolku, který přináší do stávajícího rusínského společenství oživení činnosti, zvláště rozšiření dosavadní institucionalizované spolkové základny. Poukazují přitom na rozpor, který vnímají mezi výsledky sčítání lidu a kvalifikovanými odhady, podle kterých je početnost Rusínů v ČR mno-

10 Ve výsledcích sčítání lidu v letech 1921 až 1961 jsou Rusíni uvedeni

společně v jedné kolonce pod hlavičkou Rusové a Ukrajinci, od roku 1970

byla pak národnost ruská a ukrajinská uváděna odděleně.

11 Projevilo se to i v ústavněprávní úpravě o postavení národností v ČSSR

z roku 1968 v rámci československé federace - viz pozn. 9.

12 Podle definitivních výsledků sčítání lidu v roce 1991 uvedlo v České republice rusínskou národnost 1926 osob, v roce 2001 poklesl jejich počet na 1106 osob a v roce 2011 na 739 osob. Srov. Čsú - Obyvatelstvo podle národnosti podle výsledků sčítání lidu v letech 1991-201l. Dostupné z: https://www.czso.cz/csu/ czso/demograficka-prirucka-2013 [2016-06-03]. Oproti tomu odlišný vývoj demografických ukazatelů je na Slovensku. Podle sčítání lidu v roce 1991 deklarovalo na Slovensku rusínskou národnost 17197 osob (0,3 \%) - viz http://sodb.infostat.sk/sodb/sk/1991/format.htm [2016-06-13], v roce 2001 pak 24201 osob (0,4 \%) - viz http://sodb.infostat.sk/sodb/sk/2001/format.htm [2016-06-13] a v roce 2011 se počet zvýšil na 33482 osob (0,6 \%) - viz https://census2011.statistics.sk/tabulky.html [2016-06-13]. Opačný trend přitom zaznamenává deklarování ukrajinské národnosti. V roce 1991 deklarovalo na Slovensku ukrajinskou národnost 13281 osob $(0,3$ \%) a při dalších sčítáních tento počet významně poklesl (v roce 2011 na 7430 osob). Ovšem diametrálně odlišné údaje o Ukrajincích vyplývají ze sčítání lidu v České republice, konkrétně v roce 1991 deklarovalo ukrajinskou národnost 8220 osob, v roce 2001 počet vzrostl na 22112 osob a v roce 2011 dokonce na 53253 osob. Viz https://www.czso.cz/csu/czso/ demograficka-prirucka-2013 [2016-06-13]. Je přitom zjevné, že v uvedených počtech osob se promítá př́tomnost migrantů z Ukrajiny. Z poslední evidence Českého statistického úřadu vyplývá, že v České republice k 31. 12. 2014 pobývalo 104156 Ukrajinců - viz https://www.czso.cz/csu/czso/cizinci-v-cr-2015 [2016-06-13]. Podle kvalifikovaných odhadů je však počet Ukrajinců v České republice o mnoho vyšší. 
honásobně vyšší. Zástupci SPPR ve spolupráci s organizací Rusíni.cz se tak snaží aktivizovat nejen členskou základnu obou spolků, ale i neformálních uskupení českých či jiných sympatizantů, kteří s ohledem na vztah k bývalé Podkarpatské Rusi podporují program českých Rusínů.

V Česku se Rusíni postupně začlenili do skladby národnostních menšin v 90. letech 20. století. Zástupce Rusínů (člen SPPR) se stal členem Komise Rady hl. m. Prahy pro oblast národnostních menšin a následně po přijetí tzv. menšinového zákona ${ }^{13}$ je od roku 2001 rusínský zástupce i členem Rady vlády pro národnostní menšiny, poradního orgánu vlády pro otázky týkající se národnostních menšin a jejich př́slušníků. Podobně jako ostatní národnostní menšiny mají Rusíni v současnosti svého zástupce $\mathrm{v}$ resortních orgánech pro národnostní menšiny a rovněž Výboru pro národnostní menšiny Zastupitelstva hl. m. Prahy. ${ }^{14}$ Obě rusínské organizace sídlí spolu s ostatními menšinovými spolky v pražském Domě národnostních menšin a využívají jeho prostory na pořádání vlastních akcí nebo participují na multikulturních společných pořadech menšin. Navzdory institucionálnímu ukotvení rusínské národnostní menšiny ve struktuře orgánů veřejné správy provází však Rusíny stálý proces vymezování se ve vztahu k příslušníkům ukrajinské a slovenské národnosti a stvrzování vlastního menšinového postavení.

\section{Deklarování rusínské národnosti, komponenty etnické identity}

Přináležitost k rusínské národnostní menšině považují respondenti všech věkových kategorií za významnou, a to i v případě sympatizantů SPPR české národnosti. Rozdílně je ale nahlíženo na zdůrazňování národnostní příslušnosti v soukromém a veřejném životě. I když převažuje důraz na uchovávání rusínství v rodinném životě, akcentuje se, že by příslušníci menšiny neměli svou národnostní identitu skrývat ve veřejném prostoru. $Z$ výzkumného vzorku rusínských respondentů vyplývá, že v jejich kolektivním vědomí existuje představa, že nerozlišování postoje v soukromém a veřejném životě přispívá k aktivnějšímu přístupu k uchovávání kulturních tradic a mateřského jazyka.

Deklarování rusínské národnosti spojují respondenti nejčastěji s př́íslušností k řeckokatolické církvi. Rusíni se hlásí rovněž k pravoslavné, ale i jiným církvím (nevylučuje se též postoj bez vyznání). Z hlediska občanství respondentů (ČR nebo SR) se neprojevují rozdíly v postojích k náboženskému vyznání. Obecně Rusíni přikládají církevním institucím důležitou roli, protože na liturgický kalendář se váže cyklus výročních obyčejů, který je vnímán jako součást jejich menšinového života. Při výzkumu se respondenti vyhýbali tématu rodinného obyčejového cyklu (narození, svatba, pohřeb), ale reagovali na otázku o dodržování zvyků na Vánoce a Velikonoce (příprava

13 Zákon č. 273/2001 Sb., o právech příslušníků národnostních menšin a o změně některých zákonů.

14 Viz usnesení Zastupitelstva hl. m. Prahy č. 5/66 ze dne 26. 3. 2015, ke zř́zení Výboru pro národnostní menšiny Zastupitelstva hl. m. Prahy. Dostupné z: http://www.praha.eu/jnp/cz/o_ meste/primator_a_volene_organy/zastupitelstvo/vybory_zastupitelstva/index.html [2015-08-15]. 
svátečního jídla a stolování na Vánoce a Velikonoce, svěcení velikonočních jídel - paschy apod.). Rusínští imigranti ze Slovenska slaví tyto svátky podle gregoriánského kalendáře, ale nevylučuje se možnost připravit skromnější oslavu (bez dárků) i opakovaně podle juliánského kalendáře. Praktikování zvyků vnímají jako rusínské, což se týká zvláště vánočního a velikonočního obyčejového cyklu.

Respondenti z členské základny Rusíni.cz i SPPR v průběhu řízených rozhovorů uváděli, že zvyky dodržují po rodičích Rusínech nebo i Češích, kteří žili v meziválečném období na Podkarpatské Rusi. O Vánocích na Štědrý den drží půst dle tradice východní církve. Štědrovečerní večeře (Svjatyj večur) začíná modlitbou, zpívají se koledy (koljadky). Důležitou součást jídelníčku představují moučná jídla, hlavně pirohy s různou náplní, ale i ryby. ${ }^{15}$

Zástupci spolku Rusíni.cz zdůrazňovali, že využívají možnost slavit Vánoce hlavně v prostředí původního domova na Slovensku. Pokud zůstávají s rodinou v českém prostředí, jídla servírovaná na štědrovečerní večeři by se měla co nejvíce přiblížit stolování v původním domově. Podle respondenta střední generace s vysokoškolským vzděláním mají pod stolem malý svazek sena, na stole med, oplatku, česnek apod. (17 - SR, muž, 38 let). ${ }^{16}$ Před večeří si každý člen rodiny umyje obličej ve studené vodě a pak se všichni shromáždí ke společné modlitbě, následuje zpěv koled (koljadky). Pod ubrusem na stole jsou peníze. Skladba štědrovečerního jídla: zelná či kyselá polévka s uškami (malé pirožky plněné hříbky), moučná jídla mačanka a bobalky, slivčanka, pirohy, hrachová kaše, ale i ryba s bramborovým salátem. V průběhu večeře si každý vybírá z těchto jídel podle zájmu. Nejí se čerstvé ovoce. Při jídle je zakázáno hlasitě hovořit ( 8 - SR, žena, 33 let).

Větší rozdíly potvrdili respondenti s českým a slovenským občanstvím v případě slavení velikonočních svátků. Čeští zmínili jen sporadicky malování velikonočních vajíček. A i když mají povědomí o svěcení velikonočních jídel v kostele (velikonoční paschy), podobně jako u příslušníků jiných menšin pravoslavného vyznání, praktikují tento zvyk jen sporadicky. Oproti tomu rusínští migranti ze Slovenska projevují snahu, aby měli velikonoční jídla posvěcená v rámci velikonočních obřadů v kostele. Košík s velikonočním jídlem má obsahovat velikonoční koláč (pascha), uzeninu (slanina, šunka, klobásy), barvená vajíčka, máslo, hrudku sýra, červenou řepu, křen apod. Svěcení velikonočního jídla v řeckokatolickém nebo i římskokatolickém kostele patří k těm jevům, které Rusíni vnímají jako projev vlastní identity. Na velikonočním stole nesmí chybět syrek, klobása, šunka, vařená vejce a paschalnyj chlib (17 - SR,

15 Na štědrovečerním stole by mělo být devatero jídel. Složení jídelníčku podle tradice na Podkarpatské Rusi i s popisem přípravy jednotlivých jídel vydala nejnověji samostatnou publikací SPPR (Březinová 2015: 10-15).

16 Respondent uvádí, že slavnostní úprava vánočního stolu je podobná, jak si to pamatuje z rusínského prostředí na východním Slovensku. Atmosféru původního domova oživuje i skutečnost, že suroviny na přípravu vánočních jídel mu posílají rodiče ze Slovenska. 
muž, 38 let). Většina respondentů připomínala, že v tradičním rusínském prostředí na východním Slovensku se s velikonočními svátky spojuje pořádání velikonočních zábav. Tuto tradici v povelikonočním čase oživuje v Praze spolek Rusíni.cz. Pořádání těchto zábav je vnímáno jako jeden z projevů uchovávání kolektivní identity rusínství v prostředí české většinové společnosti.

\section{Mateřský jazyk}

Výzkum potvrdil, že respondenti z členské základny Rusíni.cz pokládají uchování mateřského jazyka - podobně jako ostatní národnostní menšiny - za prioritu v menšinovém životě. Rusínští imigranti ze Slovenska tvoří přitom jazykově různorodě diferencované společenství, které mluví více dialekty rusínštiny, proto je v menšinovém společenství nahlíženo na otázku mateřského jazyka rozdílně podle místa původu, tj. z oblastí severního Spiše, Šariše či Zemplína. Odlišné morfologické jazykové znaky těchto nářečí neznamenají ovšem pro mluvčí překážku v komunikaci mezi příslušníky menšiny. Rusíni se tak považují za mluvčí rusínštiny, ale v podobě dialektů, regionálních variant „rusnáckých“ nářečí. Žádný z respondentů přitom nepotvrdil, že dovede mluvit ukrajinsky. Ukrajinština je pro ně jiný jazyk, znají ho jen částečně nebo špatně a ukrajinsky nemluví. Z výzkumného vzorku respondentů z členské základny Rusíni.cz vyplývá, že odmítavý postoj k ukrajinštině zaujímají i ti informátoři, kteří v původním domově na východním Slovensku navštěvovali školu s ukrajinským vyučovacím jazykem (25 - SR, muž, 35 let).

Je-li mateřský jazyk obvykle chápán jako něco samozřejmého, jako danost, do které se jedinec narodil, pro příslušníky rusínské menšiny jsou to regionální varianty rusínských nářečí. Jazyková situace v prostředí rusínských imigrantů je specifická také v tom, že mateřštinou hovoří pouze uvnitř vlastního menšinového společenství, ve veřejném prostoru používají slovenštinu, kterou ne zcela dokonale ovládají, nebo se snaží hovořit česky či spíše etnolektem češtiny. Postoje mluvčích k rusínštině na pozadí vícejazyčné komunikace se tedy pohybují odděleně ve dvou rovinách: na jedné straně hovoří rusínsky v soukromé sféře a spolkovém životě, na druhé straně slovensky nebo česky ve veřejném životě.

V menšinovém životě Rusínů se výše uvedené skutečnosti projevují jako jedna z otevřených otázek v oblasti výuky mateřského jazyka. V spolkové činnosti Rusínů totiž neexistuje program výuky rusínštiny jako menšinového jazyka a zástupci spolků Rusíni.cz či SPPR si nekladou ani za cíl rozvíjet aktivity se zaměřením na pořádání kurzů výuky mateřského jazyka. Důvodem je nejasnost, jak by se mělo přistoupit k výuce rusínského jazyka, který užívají v podobě dialektů. Především ale přetrvává pochybnost, zda by to měla být výuka kodifikované spisovné rusínštiny, která se používá na Slovensku (srov. Plišková 2015: 106 a n.), když snahy o její rozšíření jsou předmětem diskusí 
odborné veřejnosti i příslušníků rusínské národnosti. ${ }^{17}$ Diskuse na toto téma v členské základně Rusíni.cz i SPPR doposud prakticky ještě nezačala, objevují se jen sporadické úvahy (chybí i představa, zda by výuka měla zahrnout žáky základních škol, ale také jejich rodiče). Nicméně zástupci spolku Rusíni.cz připomínali problém osvojení si kodifikované podoby jazyka a hlavně význam používání spisovného rusínského jazyka v postavení př́íslušníků menšiny mimo území Slovenska, když jejich identifikace je vázána na regionální variety rusínštiny původního domova.

Postoj současných imigrantů ze Slovenska k mateřskému jazyku charakterizuje výpověd' informátorky střední generace - „doma rozprávame výlučne slovensky, poprípade rusnacky, takže aj naše deti vedia slovensky a rusnacky“ (8 - SR, žena, 30 let). Z dotazníkového šetření jasně vyplývá, že respondenti považují v domácím prostředí používání rusínštiny za samozřejmost - „s priatelom [pozn. A. S., tj. partnerem] i doma v rodine hovoríme rusínsky“ (21 - SR, žena, 28 let). V př́ípadě smíšeného rusínsko-slovenského manželství je komunikace v rodině závislá na př́tomnosti rodičů manželského páru, resp. postoji partnera - „rozprávam rusínsky doma s otcom, s det'mi komunikujem slovensky, aj s manželkou, ktorá nie je Rusínka“ (24 - SR, muž, 42 let).

Pokud jde o čtení rusínské literatury, respondenti jen sporadicky uvedli, že sledují informace v rusínštině na internetovém portálu Holosy.sk či InfoRusín, respektive si přečtou přílohu v rusínštině v časopise SPPR Podkarpatská Rus, nebo že se zajímají o publikace rusínských autorů (10 SR, žena, 33 let). V kodifikované podobě rusínštiny vychází sice Kvartalnyk Rusiniv v Čechach. Rodnij kraj jako př́loha časopisu Podkarpatská Rus, ale povědomí o vydávání této tiskoviny je minimální. Zaznamenaná odvolávání se na internetový portál karpatských Rusínů Holosy.sk, který věnuje zvýšenou pozornost psané podobě rusínského jazyka a rusínsko-ukrajinským vztahům, jsou vesměs indiferentní. Souvisí to zřejmě s problémy výuky rusínštiny na Slovensku, obtížemi s rozšiřováním škol s rusínským vyučovacím jazykem a především diskurzem na téma, zda mladá generace Rusínů potřebuje výuku rusínštiny, když s její spisovnou formou se v profesním životě v praxi neuplatní. Odpovídá to nejnověji i publicistické úvaze pod názvem Chto sme a de ideme Aleny Blichové, spolupracovnice redakce Podkarpatská Rus ze Slovenska (Blichová 2015). Autorka poukázala na paradoxní situaci na Slovensku v tom smyslu, že Rusíni rezignují na rozvoj rusínštiny jako mateřského jazyka a nereflektují skutečnost, že s mateřským jazykem se spojuje kultura a duchovní hodnoty etnika.

17 Na rozporné vnímání uplatňování spisovné rusínštiny na Slovensku ukázal i historickosociologický výzkum v roce 2000. Viz „Sebareflexia postavenia a vývoja Rusínov na Slovensku“ z roku 2000 (odborná spolupráca Stanislav Konečný, František Baumgartner, Miroslav Frankovský, Marián Gajdoš). Dostupné z: lemko.org/rusyn/sebareflexia.pdf [2016-06-17]. 


\section{Národnostně menšinová identita Rusínů}

Na otázku o vědomí národnostně menšinové identity Rusínů reagovali rozdílně zástupci starší generace Rusínů, tedy občané ČR (SPPR), a zástupci současné imigrační vlny ze Slovenska (Rusíni.cz). Odpovídají tomu i odlišné strategie, které se projevují v postojích k rusínské menšinové identitě: vedle vyhraněné identity rusínské je to i dvojí rusínsko-česká (či česko-rusínská) nebo rusínskoslovenská (či slovensko-rusínská) identita. Zdroje vědomí rusínské národnostně menšinové identity vidí respondenti v rodinném zázemí každého jednotlivce. V rámci členské základny SPPR si uchovává především starší generace vědomí vazby na Podkarpatskou Rus po rodičích, s nimiž spojuje vlastní národnostní identitu, např́klad: „...otec byl Čech - legionář, od poloviny 20. let minulého století působil na Podkarpatské Rusi jako berní úředník. Na Podkarpatské Rusi se oženil s Rusínkou. Měl zájem trvale se usídlit na Podkarpatské Rusi, ale v roce 1939 musel opustit nově postavený rodinný dům. S rodinou se usídlil v Praze. Manželka hovořila i $v$ Praze jen rusínsky a obtížně se v českém prostředí adaptovala. Vychovala dvě dcery, starší se narodila na Podkarpatské Rusi, druhá v Praze. Vedla je k aktivnímu osvojení rusínštiny. Od poloviny 50. let často navštěvovaly příbuzné na Podkarpatské Rusi a pouto k původnímu domovu matky znamenalo pro ně i uchovávání povědomí přináležitosti k Rusínům. “ (6 - ČR, žena 65 let) Respondentka k tomu uvedla upřesnění, že se sice cítí Češkou, ale s rusínskými kořeny, což chápe jako dvojí identitu. Výzkum také potvrdil, že ve spolkovém životě SPPR je rusínství obecně vnímáno jako stvrzování rodinných vazeb, které respondenty spojuje s územím Podkarpatské Rusi (3 - ČR, žena, 53 let).

Akcentování rusínství jako výrazu rusínské identity se odlišně projevuje v členské základně Rusíni.cz, tj. u imigrantů ze Slovenska, at již v postavení občanů ČR, nebo SR: „Hrdě se hlásím ke své rusínské menšině.“ (5 - ČR, žena, 50 let) Hrdost na rusínský původ, příslušnost k rusínské národnostní menšině vyjadřují slovenští Rusíni s ohledem na kolektivní vědomí osobitosti rusínských tradic: „Naše vědomí národnostně menšinové identity vyjadřuje pocit hrdosti na rusínské tradice. “(14 - SR, muž, 38 let) Demonstruje to i výpověd' informátorky, která žije 5 let v Praze: „snažím sa nepotláčat' svoje vlastné ja, to čo ma vystihuje a čo mi bolo mojimi predkami darované, čo ma naučili ... snažím sa byt' súčastou väčšiny aj tým, že do spoločnosti nesiem kúsok zo svojej kultúry.“(9 - SR, žena, 28 let) V individuálních postojích je sice zdůrazňován pocit svébytnosti a odlišnosti v prostředí většinové společnosti, ale i snaha o plné začlenění se do většinové společnosti při současném udržování kontaktů s vlastním menšinovým společenstvím: „nemyslím si, že samotný pocit identity je u mne důležitý, to spiše v menši míře. Hlavně u komunitních akcí vidím možnost setkávat se s blízkými lidmi, s nimiž sdílím stejné hodnoty, komunikovat s nimi.“(19 - SR, muž, 33 let)

Otázka rusínské identity nevystupuje do popředí jen u rusínských imigrantů ze Slovenska. Například Hedvika Novotná při studiu migrace z Ukrajiny po 
roce 1990 zaznamenala, že současní imigranti ze Zakarpatské oblasti - s ohledem na odlišnost rusínských dialektů od ukrajinštiny - inklinují k akcentování územní vazby na Podkarpatí, které spojují s rusínskou identitou (Novotná 2005: 352-353). Podobně odvozují rusínský původ podle oblastí historických regionů také migranti ze Slovenska.

Respondenti v průběhu řízených rozhovorů často zdůrazňovali, že mají pocit odlišnosti v majoritě, která má jinou mentalitu, jiné zvyky, jiné cítění, jiný hodnotový žebříček apod. (10 - SR, žena, 33 let). Navzdory tomu Rusíni hodnotí soužití s většinovou společností vcelku dobře. Sdílejí pocit, že přispívají k obohacení veřejného prostoru - „doplňujeme to, co možná chybí většinové společnosti, jiný náhled na vztahy, život, tradice“ (14 - SR, muž, 38 let), respektive postoj mladšího podnikatele - „přinášíme jiné názory, pohledy, zvyky“ (18 - SR, muž, 28 let). O žitém poznání soužití s př́íslušníky většinové společnosti vypovídá studentka, která usiluje o trvalé usídlení v Česku - „hlavne na začiatku bolo t’ažšie si zvyknút na povahu ludí väčšinovej spoločnosti, ale vcelku nemám $v$ tomto smere negatívne skúsenosti“ (9 - SR, žena, 28 let). Vztahů k příslušníkům jiných národností - Čechům, Slovákům, Ukrajincům, Rusům, Polákům, Mad'arům či jiným (v dotazníku označeno podle stupnice tolerantní - dobré - zlé) uvedli respondenti (až na jednu výjimku negativního postoje k Rusům) jako tolerantní a dobré. Výraz tolerance doprovodila respondentka dokonce vyjádřením: „Na světě je dost místa pro každý národ. “(5 - ČR, žena, 50 let)

\section{Imigrace Rusínů, proces usídlování}

Respondenti z členské základny Rusíni.cz patří do skupiny individuálních migrantů, kteří se v ČR usídlovali hlavně po roce 2000, jen ojediněle v 90. letech 20. století po rozdělení česko-slovenské federace. Své postavení v Česku jako občané SR vnímají oproti ostatním ekonomickým imigrantům ze Slovenska a zvláště z oblasti Zakarpatské Ukrajiny (srov. Uherek - Valášková - Bělohradská Mušinka 2008) odlišně. Většinou usilují o trvalé usídlení se v ČR. Výzkumný vzorek respondentů bydlí - až na výjimky - v Praze v nájemních či v pronajatých bytech (individuálně, nebo společně 2 osoby), ale i v bytech v osobním vlastnictví či ve vlastních domech. Jejich profesní zaměření je různorodé, jde o profese odpovídající převážně vysokoškolskému vzdělání (technické obory, IT služby, sporadicky působí respondenti s českým občanstvím jako zaměstnanci veřejné správy), v menší míře středoškolskému vzdělání (s uplatněním v manuálních profesích).

Postoj narátorů ve věku kolem třiceti let ze spolku Rusíni.cz nevylučoval možnost změnit nynější místo pobytu. Odkazováno je hlavně na vnější okolnosti; například vysokoškolská studentka, absolvující doktorandské studium, uvedla, že k rozhodnutí ještě nedospěla - „zmena závisí od mnohých okolností: práca, rodina, zázemie, bývanie, financie“ ( 9 -SR, žena, 28 let). Mladá generace sice preferuje trvalé usídlení v Česku, ale jednotlivci přistupují k definitivnímu 
rozhodnutí v závislosti na osobních i pracovních motivacích - „ešte nie som rozhodnutá, ak sa mi naskytne práca doma na Slovensku, možno sa vrátim, záleží tiež od priatela, ten sa chce vrátit na Slovensko“, proto k tomu respondentka dodává, že „nezáleží na tom, kde člověk žije, ale s kým“ (21 - SR, žena, 28 let). Podobně argumentovala jiná respondentka - ,jestli se tady trvale usídlím, závisí na vícero faktorech, predevším, zdali si tady založím rodinu“ (10 SR, žena, 33 let). Současně uvedla, že stávající místo usídlení splňuje pouze částečně představu domova - „více méně ano, ale domov to není a nikdy nebude“; v jiné souvislosti hovořila, že „pre mňa je domovom miesto, ktorého súčastou sú ludia, na ktorých mi záleží a ktorým záleží i na mne“. V nynějším postavení otázku domova odsouvala do pozadí, i když připouštěla dvojí chápání domova, tj. rodiště - původní domov a nynější/budoucí trvalé usídlení, co by mělo být pro ni důležitější. Nevyloučila ale ani možnost usídlení v jiné zemi než v ČR. Důvod je ten, že pocituje nespokojenost s uplatněním na trhu práce a frustraci z české mentality. Respondentka (9 - SR, žena, 28 let), která výše zaujala flexibilní postoj k usídlení, formulovala svůj postoj v tom smyslu, že „nezáleží na tom, kde človek žije, ak má vytvorené vhodné podmienky na to, aby sa cítil spokojný a štastný - $k$ tomu potrebuje spoločnost', vztahy, financie“. Jako vysokoškolská studentka preferuje v životě profesní uplatnění a vazbu k původnímu domovu odsouvá do pozadí. Ke změně místa usídlení v jiné zemi než ČR je více nakloněna mladá generace, která předpokládá, že se jí naskytne možnost uplatnění na trhu práce s vyšším finančním oceněním.

Odlišný postoj lze zaznamenat u stř̌ední či starší generace zástupců spolku Rusíni.cz, kteří jsou usídleni více než 20 let v ČR. Bydlí-li trvale v nájemním bytě nebo v bytě v osobním vlastnictví či ve vlastním domě, vnímají to jako nový domov: „Mám vlastní bydlení - byt, dř́ve jsem se zamýšlel nad dvojím domovem, ted'už ne, mám zde rodinu, a kde je nejbližší rodina, tam je domov, ted'je to už trvale v ČR. “(17 - SR, muž, 38 let) Z výzkumu vyplynulo, že vědomí dvojího domova vnímají respondenti v závislosti na vlastnictví nemovitosti. Pokud respondent vlastní dům nebo byt v Česku a své usídlení v ČR považuje za trvalé, ale současně je majitelem domu či má podíl na rodinném majetku na Slovensku, hovoří o dvojím domově: „Ked' cestujeme s rodinou na Slovensko, ideme domov, ale naspät' do Prahy sa vraciame rovnako domov. “ (7 - ČR i SR, žena, 58 let)

Respondenti starší generace z členské základny SPPR (občané ČR), kteří hovoří o dvojí česko-rusínské identitě, zaujímají ambivalentní vztah i k vnímání domova. Kategorie domova má pro ně dvojstranný rozměr: přítomný v Česku a současně po předcích na Podkarpatské Rusi (6 - ČR, žena, 65 let). Vztah k Podkarpatí je tedy materializován na základě postavení rodinných příslušníků, kteří jsou považováni za součást životního příběhu s nostalgickým nádechem k Podkarpatské Rusi. Domov v časové linii je spojován se vzpomínáním na minulou přináležitost, i když ne plně prožitou.

S představou dvojího chápání domova souvisí i zájem o současné politické dění na Ukrajině, zvláště situaci na území Podkarpatské Rusi. Většina 
respondentů (občané ČR i občané SR) potvrdili zvýšený zájem zejména o vývoj na Podkarpatské Rusi: „Na Podkarpatské Rusi žijí naši lidé Rusíni, dále na Ukrajině máme př́buzenstvo ... to samo o sobě stačí, abych se silně zajímala o dění na Ukrajině. “ (9 - SR, žena, 28 let) Obecně se ale ženy většinou zajímají o politické dění na Ukrajině jen částečně, nebo odmítají se tím zabývat - „to ma nezaujíma, nikdy som tam nebola“ (21 - SR, žena, 28 let).

Vztah k Ukrajině je ovšem u respondentů variabilní. Např́íklad ve skupině stř̌ední generace mužů se projevuje v členské základně obou rusínských spolků zájem o politické dění na Ukrajině, ale převládá indiferentní vztah k příslušníkům ukrajinské menšiny - „sám Ukrajince - zástupce spolků - nevyhledávám a beru to tak, že je Ukrajina za Karpaty“ (18 - SR, muž, 28 let). Oproti tomu jeden ze zástupců spolku Rusíni.cz konstatoval, že jeho zažitá znalost poměrů na Ukrajině není objektivní: „...ja som Rusín pôvodom z východného Slovenska, naša mentalita je trochu iná než na Podkarpatskej Rusi. Slovenskí Rusíni nie sú až tak politicky a autonómne motivovaní. “(12 - SR, muž, 31 let) Charakteristické pro rusínské migranty - nezávisle na generačních skupinách - je dominance vztahu k původnímu domovu, který zaznívá i na sociální síti, například: „Pozdravuji z dalekoho kraja milych Rusnakov v mojej domovini, vyše 33 rokiv žiju u Prahy, no na Rusnakiv nedam dopustiti, mam rada naše špivanky. “18

\section{Vnitřní komunikace rusínské menšiny}

Zásluhou používání internetu tvoří Rusíni vnitřně provázanou komunitu. Byt je spolková členská základna Rusíni.cz územně rozptýlená, sociální sítě jim pomáhají rozvíjet vzájemné vazby, poskytovat si informace o možnostech účastnit se společenských a kulturních akcí spolku. Podobnou povahu personálních sítí identifikovala analýza ukrajinských imigrantů v Plzni autorů Petra Vašáta a Josefa Bernarda, kteří ukázali na význam sociálních sítí, jež využívají imigranti v rámci etnické komunity (Vašát - Bernard 2015). Aktivní uživatelé sociální sítě (facebook) Rusnaci v Prahe, ${ }^{19}$ kteří reflektují činnost organizace Rusíni.cz, představují podle statutárního zástupce tohoto spolku koncem roku 2015 téměř 1000 registrovaných účastníků. Na platformě Rusnaci v Prahe komunikuje cca 400 uživatelů facebooku z České republiky a více než 300 ze Slovenska, z nichž část se postupně usídluje v Česku. Ostatní uživatelé této platformy jsou z Ukrajiny, Polska, Srbska a dalších evropských i mimoevropských zemí. Skladbu uživatelů přibližně tvoří z 52 \% muži a 48 \% ženy, ve věku 13 až 65 let a výše. Nejpočetněji je zastoupena věková skupina 25 až 34 let (21 \% ženy a 19 \% muži), následuje skupina 35 až 44 let (8 \% ženy a $11 \%$ muži), dále skupina 18 až 24 let (7 \% ženy a 8 \% muži), skupina 45 až 54 let (7 \% ženy a 6 \% muži) a další méně významné segmenty. ${ }^{20}$

http://rusnaci1.blog.cz/1001/rusini-privitali-svoj-novy-rok [2015-09-17].

Viz https://www.facebook.com/Rusnaci-v-Prahe-260466548317/ [2016-01-05].

Přehled zpracoval M. V., písemné sdělení ze dne 30. 8. 2015. 
Z uvedeného vyplývá, že věková skladba mužů a žen je vyrovnaná. Na podněty mediátora o pražských společenských a kulturních aktivitách Rusínů reagovalo několik stovek uživatelů facebooku. Statutární zástupce spolku zvlášt pozitivně hodnotí skutečnost, že na jejich platformě sociální sítě komunikují nejenom Rusíni, ale i jejich sympatizanti. Představitel spolku Rusíni.cz identifikuje silnou skupinu uživatelů zmíněné sociální sítě u mladé generace z Česka a rovněž z východního Slovenska, kteří aktivně projevují zájem o společenské a kulturní akce Rusínů žijících v Česku. Vypovídá o tom komunikace ze strany českých i slovenských uživatelů, například: „Pozdravuju Rusnakiv a praju štastny Novy rik a aj v dalších rokoch oslavujte rusnackij Silvester a Novi rik, "21 nebo: „Náhodou jsem objevil tenhle blog a díky za něj. I když jsem Čech, předky mam ze Zboje [pozn. A. S. - obec v okrese Snina], ještě tam máme dům ... fandím tomuhle blogu i rusnáckýmu jazyku ... otec dodnes slaví Vánoce po vašem ... pirohy, holubky a nebo leveš je stále na našem jídelníčku. “22

Podle statutárního zástupce spolku Rusíni.cz zájem uživatelů sociální sítě o některá témata týkající se Rusínů (jejich historie, používání rusínštiny jako spisovného jazyka, postavení Rusínů jako menšiny, jejich ohrožení asimilací v jinoetnickém prostředí apod.), kterým se věnuje zvýšená pozornost na webových stránkách Holosy.sk, je nízký. Podobně ani politické otázky o vztahu Rusínů k oblasti Zakarpatské Ukrajiny (či Ukrajiny vůbec) uživatele sociální sítě nepřitahují. Pokud se sporadicky zapojují do komunikace na sociální síti Rusíni z Ukrajiny, deklarující zejména svůj původ z oblasti Podkarpatí, nastolují sice politická témata, ale reakce na ně je malá. Pozornost mladé generace - uživatelů sociální sítě - se projevuje především zájmem o společenské a kulturní aktivity Rusínů. Na sociálních sítích se rovněž jen zřídka objevují příspěvky o sociálních problémech migrantů, o pomoci při uplatnění na trhu práce apod. Zástupci spolku Rusíni.cz proto nepovažují za vhodné zabývat se na síti otázkami sociálního postavení či zaměstnanosti imigrantů. Postavení Rusínů hodnotí v tom smyslu, že tvoří integrovanou a stabilizovanou součást většinové společnosti. Komunikace na sociální síti je záležitostí spontánní, zásluhu na tom má mediátor, který přispívá informacemi např́íklad o hudebních skupinách, v nichž působí Rusíni, ${ }^{23}$ historkami ze života Rusínů apod. A na tyto podněty reaguje bezprostředně i širší okruh uživatelů sítě z Česka a Slovenska.

Za specifický jev v prostředí rusínského společenství lze považovat proces vnitřní mezigenerační diferenciace. Př́ílušníci nejstarší generace členů SPPR,

21 Viz https://www.facebook.com/Rusnaci-v-Prahe-260466548317/ [2016-01-05].

22 Tamtéž.

23 Například hudební skupina Apollon, která vznikla ve Svidníku v roce 1998 a od roku 2000 působí v České republice. Mezi zakladatele skupiny patří Peter Nastišin, který stál i u zrodu spolku Rusíni. cz. Skupina pravidelně účinkuje na rusínských plesech a zábavách v Praze. Podobně informuje o známé hudební skupině Kandráčovci, populárním herci a moderátorovi Michalu Hudákovi na Slovensku, který se hrdě hlásí k rusínské národnosti a rusínskému mateřskému jazyku, apod. 
kteří se jako imigranti po první světové válce trvale usídlili v českých zemích, a v současnosti i jejich potomci vnímají citlivě vztah k bývalé Podkarpatské Rusi. Je jim blízká rovněž myšlenka čechoslovakismu. K těmto Rusínům se hlásí i starší generace Čechů (sympatizantů SPPR), pokud uchovávají v kolektivní paměti obraz rodinných příslušníků, kteří v meziválečném období na Podkarpatské Rusi působili. Oproti tomu střední a mladá generace imigrantů z východního Slovenska z členské základny Rusíni.cz neprojevuje zájem o vazby na Podkarpatskou Rus. Svou identitu spojují s deklarovaným rusínstvím a „rusnáckým“ jazykem, rusínským dialektem odlišným od ukrajinštiny. Podobně podle výzkumů Hedviky Novotné je otázka rusínské identity spojována u současných imigrantů ze západní Ukrajiny v Česku hlavně s jazykem. Dokládá to výpověd' respondentky: „My v Zakarpatí jsme Ukrajinci, ale nemohu ř́ci, že jsem Ukrajinka, jsem prostě Rusínka. To souvisí predevším s mateřským jazykem: my nemluvíme ukrajinsky ... čistý Ukrajinec nám vůbec nerozumí ... také zvyky jsou trošku jiné než např́iklad na Ukrajině.“ (cit. dle Novotná 2005: 352, 353) Analogické postoje zajímají i rusínští imigranti ze Slovenska v spolku Rusíni.cz, kteří se jednoznačně považují za příslušníky samostatné rusínské národnosti, odlišné od ukrajinské.

\section{Spolkový život}

Spolkový život Rusínů je vnímán jako jedinečný prostor pro stvrzování národnostně menšinové identity. Jeho průvodním jevem je mj. reflexe postavení menšiny, vlastní kladné hodnocení přítomnosti ve většinové společnosti. Platíli obecně, že menšina obohacuje většinovou společnost, z odpovědí respondentů jednoznačně vyplývá, že sdílejí pocit o své úloze přispívat k obohacování veřejného prostoru, zejména kulturním vkladem. Respondenti ale současně poukazují na to, že většinová společnost zaujímá nejen vůči Rusínům, ale i ostatním menšinám rezervovaný postoj. Starší generace českých Rusínů a sympatizantů SPPR hovoří proto o zapomínání na Rusíny ve většinové společnosti.

Pokud jde o členskou základnu rusínských organizací působících hlavně v Praze, rámcově se člení - jak uvedeno výše - na dvě části. Trvale usídlená starší generace Rusínů se statusem českého občanství dává přednost členství v SPPR, oproti tomu mladší generace imigrantů ze Slovenska, která se sdružuje v spolku Rusíni.cz, se prohlašuje za slovenské Rusíny. Výzkumný vzorek zástupců rusínské menšiny ovšem ukazuje, že častým jevem je duplicita členství. Např́iklad informátorka z Trutnova nepovažuje za vhodné účastnit se aktivit jen v jednom spolku. Na spolkovém životě oceňuje to, že má možnost být v kontaktu s lidmi, kteří - jak říká - „mluví mojí řečí a chápou moji kultu$r u, v$ jejich společnosti mám pocit vlastní seberealizace" (5 - ČR, žena, 50 let). Noví rusínští imigranti ze Slovenska vyhledávají kontakt především na spolek Rusíni.cz, i když formalizovanému členství ve spolku nepřikládají větší 
význam: „Členstvo sme zatial'neriešili, ale vel'mi radi navštevujeme akcie organizované spolkom Rusíni.cz, či už ide o zábavy, plesy, prednášky, máme tak pocit domova. " (8 - SR, žena, 30 let) Společenské rusínské akce jsou vnímány jako příležitost k setkávání s mentálně blízkou rusínskou společností (12 - SR, muž, 31 let).

$\mathrm{Na}$ činnosti rusínských spolků se jejich členové podílejí různou měrou. Zájem o spolupráci je u členů spolku Rusíni.cz zejména při pořádání plesů, tanečních zábav či koncertů. V případě SPPR se zájem o systematickou spolkovou práci projevuje v menší míře, nicméně oba spolky spolehlivě fungují; aktivně pracuje redakce časopisu Podkarpatská Rus (vydává SPPR). Prioritou v činnosti obou spolků je pořádání kulturně-společenských akcí, besed, přednášek, workshopů, vzdělávacích akcí, výstav, vystoupení hudebních a pěveckých souborů.

Spolek Rusíni.cz nepočítá s budováním velké členské základny (v současnosti registruje cca 40 členů). Nicméně se snaží oslovovat širší okruh nejenom př́islušníků rusínské menšiny, ale i sympatizantů většinové společnosti. Vedení spolku proto klade důraz na to, aby se jeho činnost rozvíjela i na neformální bázi jako otevřené společenství. Jedna z respondentek to formulovala takto: „Je dôležité mat okolo seba vlastných ludí, medzi ktorými sa cítim dobre, ako doma. Spolok je vel'mi dôležitý, bez neho by som uvažovala, že sa na dôchodok vrátim domov na Slovensko. V spolkovom živote nachádzam druhý domov. “(7 - ČR i SR, žena, 58 let) Pro příslušníky rusínské menšiny znamená členství ve spolku Rusíni.cz udržování osobních kontaktů, možnost setkávání se s lidmi „s podobnou mentalitou, prípomínání si svého rodiště, rodného města, respektive blízkých vesnic" (17 - SR, muž, 38 let). Často je akcentováno, že jde o setkávání se s lidmi ze stejného regionu, kteří mají na zřeteli, aby kultura rusínské menšiny žila nadále (18 - SR, muž, 28 let).

Výzkum neprokázal, že by se ve vnitřním spolkovém životě Rusínů projevovala polarita či rozdělování s ohledem na status občanství (ČR nebo SR). V kolektivním vědomí rusínského společenství je oceňován angažovaný přístup vedení spolku Rusíni.cz, medializace činnosti a snaha o zviditelňování postavení Rusínů v ČR na celospolečenské i mezinárodní úrovni. Jejich aktivity se sice odvíjejí od malé skupiny slovenských Rusínů, ale akceptuje je vedení SPPR. Spolkovou činnost Rusíni.cz hodnotí pozitivně mj. z toho důvodu, že je vnímána jako spojovací článek soudržnosti rusínských komunit a prostředník posilování sociálně menšinových vztahů.

Pokud jde o charakteristiku organizačních uskupení SPPR a Rusíni.cz, rozdíly se projevují ve vnitřní diverzitě členské základny. V SPPR převládá členění společenství podle rodinných tradic, tedy na jedné straně potomků imigrantů trvale usídlených v ČSR po první světové válce, na druhé straně bývalých českých zaměstnanců na Podkarpatské Rusi a jejich rodinných příslušníků, kteří nuceně opustili území Podkarpatské Rusi v roce 1939, respektive přesídlenců po druhé světové válce. Oproti tomu spolek Rusíni.cz. představuje 
společenství slovenských Rusínů vnitřně diferencované v návaznosti na místo původu z východoslovenských regionů i sociální status v ČR. Zástupci spolku to považují za obohacující prvek v menšinovém životě; podobně nahlížejí i na různorodou skladbu uživatelů vlastní sociální sítě, která podle nich odpovídá charakteru jiných zájmových skupin na sociálních sítích.

\section{Náboženský život}

Pražští Rusíni se nediferencují podle příslušnosti k řeckokatolické nebo pravoslavné církvi: „Rusnák je gréckokatolík alebo pravoslávny, každý to rieši individuálne, dôležité je, čo nás spojuje, navzájom pritahuje, to ani neviem opísat', asi rusínska mentalita - družnost', vzájomná pomoc.“(12 -SR, muž, 31 let) Církevní svátky Vánoce a Velikonoce slaví ale většinou dvakrát, podle gregoriánského i juliánského kalendáře. Velikonoční svěcení jídel v košíku - paschy v kostele (v Praze v chrámu sv. Klimenta) je vnímáno jako součást rusínské identity. Pokud slaví svátky i podle juliánského kalendáře, rozdíl je v tom, že se již neodbývají v intimitě rodiny. Sváteční termín podle juliánského kalendáře je chápán jako příležitost k navštěvování příbuzných a známých.

V náboženském životě sdílejí Rusíni řeckokatolického i pravoslavného vyznání společné duchovní hodnoty. V Praze i pravoslavní věřící navštěvují řeckokatolické bohoslužby v chrámu sv. Klimenta, společně světí velikonoční jídla a spojuje je také to, že dávají přednost staroslověnské liturgii. Z rozhovorů vyplynulo, že většina Rusínů je řeckokatolického vyznání, a pokud se jim nenaskytne příležitost účastnit se řeckokatolické liturgie, navštěvují spíše římskokatolické bohoslužby. Podle sdělení informátorky střední generace slovenští Rusíni hlásící se k pravoslavné církvi přitom nevyhledávají pravoslavné bohoslužby, například v pražském katedrálním chrámu sv. Cyrila a Metoděje, nebot' „tam sú Rusi, Ukrajinci a ini““ (7 - ČR i SR, žena, 58 let).

\section{Perspektiva rozvoje menšinového života Rusínů}

I když se naše úvaha opírá o poznatky z omezeného výzkumného vzorku respondentů, v prostředí členské základny spolku Rusíni.cz platí, že prioritou jeho činnosti je rozvíjet společenské a kulturní aktivity Rusínů v Praze, působit na uchování rusínské identity a prezentovat Rusíny jako samostatnou národnostní menšinu. V spolkovém životě organizace Rusíni.cz existuje též potenciál osobností, které pozitivně ovlivňují kolektivní vědomí příslušníků mladé generace rusínské menšiny. Klíčovou otázkou je instrumentalizace etnických znaků. Akcentovány jsou projevy lidové kultury (rodinné i výroční zvyky, tradiční strava), zvláště hudební (folklorní) tradice východoslovenských Rusínů (účinkování ženského pěveckého sboru, připravováno je založení dětského folklorního souboru ap.), které jsou spojovány s původním domovem v oblastech rusínského usídlení na severovýchodním Slovensku. V kolektivním 
vědomí je tak stvrzován postoj, že Rusnáci - Rusíni z východního Slovenska v Česku představují autonomní skupinu, odlišnou od ukrajinské menšiny.

K otázce perspektivy rozvoje rusínské menšiny v ČR zaujala část respondentů neutrální postoj. V rámci členské základny SPPR byl však zaznamenán ojediněle i pesimistický či dokonce negativistický názor, že v budoucnosti rusínská menšina v ČR zanikne (11 - ČR, 26 let). Jako důvod je uveden silný proces asimilace Rusínů v českém prostředí a nízké menšinové sebevědomí.

Oproti tomu zástupci spolku Rusíni.cz nahlížejí na perspektivu rozvoje rusínské menšiny v ČR odlišně. V návaznosti na postavení Rusínů na Slovensku vidí pozitivně další rozvoj menšinového života Rusínů i v ČR: „Díky medializaci a aktivní činnosti různých spolků a organizací $v$ SR a $v$ ČR se menšina Rusínů dostává hodně do popredí na celospolečenské i mezinárodní úrovni.“(10 - SR, žena, 33 let, usídlena v ČR 8 let) Respondent, který profesně působí v oblasti IT a na sociální síti plní roli rusínského spiritus movens, zastává názor, že „perspektiva rozvoje rusínského menšinového života $v$ ČR je velmi dobrá, komunita se rozrůstá, členové mají relativně stabilní profesní postavení ve většinové společnosti“ (19 - SR, muž, 33 let). V prostředí členské základny SPPR, ale i stř̌ední generace zástupců spolku Rusíni.cz, byla v průběhu výzkumu zaznamenána určitá obava o další rozvoj menšinového života Rusínů: „bojím se, že se pomalu vytrácejí [tj. Rusíni - pozn. A. S.], ale spolek Rusíni.cz dělá pro Rusíny moc práce, a fandím jim." (14 - SR, muž, 38 let)

V rámci řízených rozhovorů se zástupci spolku Rusíni.cz padla i otázka, zda dovedou srovnat perspektivu vývoje rusínské a ukrajinské menšiny v Česku. Je pozoruhodné, že k situaci ukrajinské menšiny se nikdo z respondentů nevyjádřil, odkazováno bylo pouze na odlišné postavení ukrajinské menšiny v souvislosti s migrací z Ukrajiny. Tento postoj svědčí o tom, že proces národnostně menšinové identity Rusínů vychází hlavně ze sebevymezování vůči Ukrajincům v dichotomii „My“vs. „Oni“, a to s akcentováním rusínské svébytnosti.

\section{Závěrem}

S narůstajícím přílivem Rusínů ze Slovenska do českých zemí vnímá mladá generace migrantů ve spolku Rusíni.cz potřebu rozvíjet společenské a kulturní aktivity nejenom uvnitř rusínského společenství, ale i ve veřejném prostoru. Neoddělitelnou součástí tohoto konceptu je kolektivní vzpomínání na současné postavení Rusínů na Slovensku a reflektování jejich společenských a kulturních menšinových aktivit. Příhodné je proto na tomto místě připomenout studii o ukrajinských spolcích na území ČR Markéty Bezouškové, která k výkladu uvedla jako motto nahlížení Dušana Drbohlava na vývoj reprezentace menšin: „Menšina si musí sama zvolit svou budoucí roli, jakou chce hrát v majoritní společnosti, a poté se vydat na jasnou cestu dosažení tohoto cíle,“(Bezoušková 2008: 141) což odpovídá i charakteristice vybraného vzorku 
Rusínů v ČR. Rusínští imigranti ze Slovenska se nejenom etablovali v národnostně menšinové skladbě ČR, ale disponují i novými zdroji v podobě aktivit, které rozvíjejí program menšinové činnosti. Ten se opírá o vědomí rusínství, at už je územně spojováno s oblastmi východního Slovenska, vlastních kulturních tradic, nebo vymezování vůči ukrajinským migrantům nejenom z oblasti Zakarpatské Ukrajiny, ale i Ukrajiny vůbec. Za významné lze přitom považovat zjištění, že respondenti spolku Rusíni.cz potvrzovali, že se jako jednotlivci nesetkávají s problémy adaptace v českém prostředí, v každodenním životě komunikují slovensky, respektive se přizpůsobují hovorové češtině.

Poznatky z výzkumu vybraného vzorku respondentů spolků Rusíni.cz i SPPR prokazují, že zástupci Rusínů cíleně demonstrují vlastní kulturní osobitosti a s ohledem na historické peripetie zdůrazňují i specifické postavení ve skladbě národnostních menšin ČR. Průvodním jevem v menšinovém životě Rusínů je sebevymezování vůči Ukrajincům a zdůrazňování, že mentální charakteristika Rusínů je od Ukrajinců odlišná.

Ve spolkovém životě příslušníků organizace Rusíni.cz je patrná jejich deklarovaná jinakost pohledem subjektivní odlišnosti nejenom vůči Ukrajincům, ale i ostatním národnostně menšinovým společenstvím. Zdroje menšinové identity Rusínů v tomto případě ukazují na jedné straně na individuální zdůrazňování rusínství, na druhé straně na kolektivní vědomí o potřebě uchovávání a rozvoje společenského a kulturního menšinového života. Je ale pozoruhodné, že zástupci spolku Rusíni.cz nehledají při pořádání svých akcí záštitu osobností z oblasti kulturního života, tedy v Česku působících uměleckých elit, které se více či méně hlásí k Rusínům (na řadu z nich ukazují zástupci SPPR, např. Pilátová 2015; Březinová - Čopík 2015: 191-198). Uměleckých osobností také nevyužívají jako symbolu k prezentaci rusínství. Spolkové aktivity směřují k vybudování vlastní platformy s důrazem na autonomní společenskou a kulturní činnost a s cílem zviditelnit přítomnost Rusínů jako národnostní menšiny v ČR.

\section{Červen 2016}

\section{Literatura}

Bama, Fedor (ed.). 1994. Rusíni: otázky dejín a kultúry: Rusiny: voprosy istorii i kultury. Prešov: Rusínska obroda.

Bezoušková, Markéta. 2008. Ukrajinské spolky na území ČR. In: Bittnerová, Dana - Moravcová, Mirjam (eds.): Etnické komunity v kulturním kontextu. Praha: Ermat Praha, s. r. o.: 141-171. Blichová, Alena. 2015. Chto sme a de ideme. In: Kvartalnyk Rusiniv v Čechách. Rodnij kraj. Dodatok do novinky Podkarpatská Rus (Praga-Prjašiv).
Podkarpatská Rus. Časopis Společnosti přátel Podkarpatské Rusi: 1: 15.

Březinová, Dagmar. 2015. Prostřeno na Podkarpatské Rusi. Praha: Společnost přátel Podkarpatské Rusi.

Březinová, Dagmar - Čopík, Jan. 2015. Rusíni a migrace. In: Sulitka, Andrej Uherek, Zdeněk (eds.): Praha a menšiny. Praha: Etnologický ústav AV ČR - Dům národnostních menšin: 191-198.

Gajdoš, Marián a kol. 2001. Rusíni/ Ukrajinci na Slovensku na konci 20. 
storočia. K vybraným výsledkom historicko-sociologického výskumu v roku 2000. Prešov: Universum.

Hořec, Jaromír. 1998. Národnost rusínská. In: Praha a národnosti. Sborník referátů a diskusních príspěvků ze semináře o národnostních menšinách na území hl. $m$. Prahy 19. 3. 1998. Praha: Odbor školství, mládeže a tělovýchovy MHMP: 87-90.

Hubený, David. 2012. Problematika Podkarpatské Rusi. In: Tóth, Andrej - Novotný, Lukáš - Stehlík, Michal: Národnostní menšiny $v$ Československu 1918-1938. Od státu národního ke státu národnostnímu? Praha: Univerzita Karlova v Praze: 128-176.

Magocsi, Pavel Robert. 2014. Národ odnikud. Ilustrované dějiny karpatských Rusínů. Užhorod: Vydavatelství V. Pad'aka.

Matola, Rudolf. 2001. Historie Rusínů v Praze. Praha: Obsčestvo Rusínů v České republice.

Novotná, Hedvika. 2005. Imigrace z Ukrajiny v České republice po roce 1990. In: Bittnerová, Dana - Moravcová, Mirjam a kol.: Kdo jsem a kam patřím? Identita národnostních menšin a etnických komunit na území České republiky. Praha: Centrum výzkumu vývoje osobnosti a etnicity při FHS UK: 347-362.

Pilátová, Agáta. 2015. Praha, místo pro Rusíny. In: Sulitka, Andrej - Uherek, Zdeněk (eds.): Praha a menšiny. Praha: Etnologický ústav AV ČR - Dům národnostních menšin: 53-58.

Plišková, Anna (ed.). 2008. Rusínska kultúra a školstvo po roku 1989. Prešov: Prešovská univerzita v Prešove, Ústav rusínskeho jazyka a kultúry. Plišková, Anna. 2015. Rusínsky jazyk na Slovensku 20 rokov po kodifikácii. In: Sulitka, Andrej - Uherek, Zdeněk (eds.): Praha a menšiny. Praha:

Etnologický ústav AV ČR - Dům národnostních menšin: 103-124.

Pop, Ivan. 2011. Dějiny Rusínů. Podkarpatská Rus (Zakarpatská oblast) v SSSR a na Ukrajině (1946-2004). [2015-07-

06] Dostupné z: http://www.rusyn. sk/index.php?ID $=5811 \& \mathrm{l}=\mathrm{sk}$

Sebareflexia postavenia a vývoja Rusínov na Slovensku. 2002. Prešov: Róbert Vicovydavatel'stvo. [2016-06-17] Dostupné z: lemko.org/rusyn/sebareflexia.pdf.

Sopoliga, Miloslav. 1997. K problematike vývoja etnickej menšiny RusínovUkrajincov na Slovensku. Etnologické rozpravy 4, 1-2: 88-97.

Sopoliga, Miloslav. 2002. K problematike etnickej historie a národnostnej identifikácie Ukrajincov na Slovensku. Etnologické rozpravy 9, 2: 57-71.

Ševčenko, V. Kirill. 2006. Rusiny i mežvojennaja Čechoslovakija. $K$ istorii etnokulturnoj inženerii. Moskva.

Timkovič, V. Jozafát. 2006. Rusíni na Slovensku v cirkevných dokumentech. I. diel. Užhorod: Vydavatel'stvo V. Padáka. Uherek, Zdeněk - Valášková, Nad'a Bělohradská, Kateřina - Mušinka, Mikuláš. 2008. Pracovní migrace ze Zakarpatské Ukrajiny do České republiky. In: Uherek, Zdeněk - Korecká, Zuzana - Pojarová, Tereza a kol.: Cizinecké komunity z antropologické perspektivy: vybrané prípady významných imigračních skupin v České republice. Praha: Etnologický ústav AV ČR: 119-146.

Vašát, Petr - Bernard, Josef. 2015. Formování komunit, nebo sociální integrace? Analýza personálních sítí ukrajinských imigrantů v Plzni. Sociologický časopis 51: 199-226. 